\title{
ON MODIFIED NOOR ITERATIONS FOR NONEXPANSIVE MAPPINGS
}

\author{
Yonghong YaO, MuHAmmad ASlam NoOR ${ }^{1}$ And YeOnG-Cheng LiOU ${ }^{2}$
}

\begin{abstract}
In this paper, we suggest and analyze some new iterative methods for finding the fixed point of nonexpansive mapping in Banach spaces, which are called modified Noor iterations. We show that the approximate solution converges to a fixed point of the nonexpansive mapping, which is a solution of a variational inequality, under some mild conditions. Results obtained in this paper may be viewed as a significant refinement of the previously known results in this area.
\end{abstract}

Mathematics subject classification (2000): 49J40, 47H09, 47H10. point.

Key words and phrases: Strong convergence, modified Noor iteration, nonexpansive mapping, fixed-

\section{REFERENCES}

[1] F. E. BRowder, W. V. Petryshyn, Construction of fixed points of nonlinear mappings, J. Math. Anal. Appl. 20 (1967), 197-228.

[2] C. BYRNE, A unified treatment of some iterative algorithms in signal processing and image reconstruction, Inverse Problems 20 (2004), 103-120.

[3] C. I. Podilchuk, R. J. Mammone, Image recovery by convex projections using a least-squares constraint, J. Opt. Soc. Amer. 7 (1990), 517-521.

[4] B. HALPERN, Fixed points of nonexpansive maps, Bull. Amer. Math. Soc. 73 (1967), 957-961.

[5] S. REICH, Strong convergence theorems for resolvents of accretive operators in Banach spaces, J. Math. Anal. Appl. 75 (1980), 128-292.

[6] N. SHIOJI, W. TAKAHASHI, Strong convergence of approximated sequence for nonexpansive mappings, Proc. Amer. Math. Soc. 125 (1997), 3641-3645.

[7] R. Wittmann, Approximation of fixed points of nonexpansive mappings, Arch. Math. 58 (1992), 486-491.

[8] H. K. XU, Another control condition in an iterative method for nonexpansive mappings, Bull. Austral. Math. Soc. 65 (2002), 109-113.

[9] H. K. XU, Viscosity approximation methods for nonexpansive mappings, J. Math. Anal. Appl. 298 (2004), 279-291.

[10] A. MoUdAFI, Viscosity approximation methods for fixed points problems, J. Math. Anal. Appl. 241 (2000), 46-55.

[11] M. Aslam NoOR, New approximation schemes for general variational inequalities, J. Math. Anal. Appl. 251 (2000), 271-229.

[12] M. ASLAM NOOR, Three-step iterative algorithms for multivalued quasi-variational inclusions, J. Math. Anal. Appl. 255 (2001), 589-604.

[13] M. Aslam Noor,, Some developments in general variational inequalities,, Appl. Math. Computation 152 (2004), 199-277.

[14] Y. YAO AND M. ASLAM NOOR, On viscosity methods for variational inequalities, J. Math. Anal. Appl. 325 (2007), 776-787.

[15] Y. Su, X. QIN, Strong convergence of modified Noor iterations, International J. Math. Math. Sci. (2006), $1-11$.

[16] T. SUZUKI, Strong convergence of Krasnoselskii and Mann's type sequences for one-parameter nonexpansive semigroups without Bochner integrals, J. Math. Anal. Appl. 305 (2005), 227-239. 
[17] M. Aslam NoOR, General variational inequalities and nonexpansive mappings, J. Math. Anal. Appl. 331 (2007), 810-822.

[18] M. ASLAM NOOR AND A. BNOUHACHEM, On an iterative algorithm for general variational inequalities, Appl. Math. Computation 185 (2007), 155-168.

[19] M. ASLAM NOOR AND Z. HUANG, Three-step methods for nonexpansive mappings and variational inequalities, Appl. Math. Computation 187 (2007), 680-685.

[20] M. Aslam Noor, K. InAYAT NoOR And TH. M. Rassias, Some aspects of variational inequalities, J. Comput. Appl. Math. 47 (1993), 285-312.

[21] T. SUZUKI, Moudafi's viscosity approximation with Meir-Keeler contraction, J. Math. Anal. Appl. 325 (2007), 342-352.

[22] I. Chryssoverghi, I. Coletsos AND B. KoKKInIS, Discretization methods for noconvex control problems with state constriants, J. Comput. Appl. Math. 191 (2006), 1-31.

[23] I. Chryssoverghi, I. COLETSOS AND B. KOKKINIS, Discretization methods for noconvex control problems with state constriants, Numer. Funct. Anal. Optim. 26 (2005), 321-348.

[24] I. Chryssoverghi, I. COLETSOS AND B. KOKKINIS, Approximate relaxed descent method for optimal control problems, Control Cyber. 30 (2001), 384-404.

[25] I. ChrYSSOVERGHI, A. BACOPOUlOS I. COLETSOS AND B. KoKKINIS, Discrete appromation of nonconvex hyperbolic optimal control problems with state constraints Approximate relaxed descent method for optimal control problems, Control Cyber. 27 (1988), 29-50. 